\title{
APPLICATION OF A GUIDED INQUIRY LEARNING MODEL ASSISTED BY A STUDENT WORKSHEET TO IMPROVE HIGH SCHOOL STUDENTS' ANALYTICAL SKILLS
}

\author{
Lelitya Nurmawati* and Dian Novita \\ Chemistry Education Study Program, Faculty Mathematics and Natural Science, State University of Surabaya, \\ Surabaya, Indonesia \\ *Email: lelityanm65@gmail.com
}

Accepted: January 14, 2022. Approved: January 14, 2022. Published: January 23, 2022

\begin{abstract}
This study aims to determine the guided inquiry learning model's implementation effect on students' activities, students' analytical skills, and student responses on the reaction rate material. This study used the one-group pretest-posttest design. The subjects in this study were students of the eleventh grade of IPA 1 at SMA Kemala Bhayangkari 1 Surabaya. The instruments used include learning model implementation sheets, student activity sheets, analytical ability test sheets, and student response questionnaires. The results showed that (1) the quality of the guided inquiry learning model application during two meetings from phase one to six are in very good criteria. (2) The activities of students in two meetings have the percentage of activity time related to analyzing at the first and second meetings of $77.2 \%$ and $81.99 \%$, respectively. (3) The results of the analysis ability of students with a percentage gain score are $85.81 \%$ on the high criteria. (4) The percentage of student responses, $87 \%$, agrees that learning using the guided inquiry learning model can train and improve analytical skills.
\end{abstract}

Keywords: Guided Inquiry Model, Analysis Ability, Reaction Rate

\section{INTRODUCTION}

Education is defined as a conscious and planned effort to present an atmosphere and learning process. Students can actively develop their potential and abilities to have personality, intelligence, skills, and self-control [1]. In chemistry, will be study theories, descriptions, and experiments that will be linked [2]. In chemistry, some sub-materials have conceptual properties, one of which is a factor that affects the rate of reaction. The characteristics of the sub-material factors that affect the rate of this reaction are that it requires proof that can be done by carrying out experiments.

In contrast, the activities carried out are observing, investigating, analyzing, and concluding experiments based on the data obtained [3]. The reaction rate is one of the chemical studies that demands the study of macroscopic, microscopic, and symbolic aspects [21]. The rate of reaction in high school is still taught through lecture and discussion methods to memorize most reaction rate concepts [22]. Until now, the reaction rate material is classified as not easy to understand; according to the data from a pre-research questionnaire at Kemala Bhayangkari 1 High School Surabaya, 83.3\% of students classify the reaction rate material as chemical material that is difficult to understand.

Analytical skills are the ability to describe a problem into smaller components or parts while also understanding and analyzing the relationships of these components [4]. Students' ability in the analysis is essential to be trained and improved due to its follow Permendikbud No. 20 of 2016, which essentially states that graduates of secondary education units are expected to have competence in three aspects, namely attitudes, cognitive, and skills [5]. In the cognitive aspect, students are expected to understand the ability or skills in analysis; therefore, it is important to train students' analytical skills. Ability in the analysis consists of three components: elemental analysis, relationship analysis, and organizational principles [6].

Learning activities in schools currently lack training in analytical skills, as evidenced by the results of pre-research questionnaires. The results of the preresearch questionnaire at SMA Kemala Bhayangkari 1 Surabaya were $88.9 \%$ of students had never carried out activities or activities related to elemental analysis components. $86.1 \%$ had never carried out relationship analysis activities, and $77.7 \%$ had not carried out activities related to the components of the analysis of organizational principles when learning activities. The data proves the lack of activities that train students' analytical skills. Another indicator that proves the statement above is the result of pre-research questions on analytical skills, which includes three components of analysis, namely analysis of elemental, analysis of the relationship, and analysis of organizational principles, which successively results in the completeness of $40.3 \%$; $39.8 \%$; and $47.9 \%$. Based on these results, in learning, a learning model is needed that can be used to help students to practice analytical skills. An example of a learning model that can be applied is guided inquiry.

The inquiry model can be defined as a series of learning activities that are more concerned with activities that require the ability or skill to think critically and analytically [7]. Activities in this learning can be used to direct students to find and understand concepts independently, of course with assistance in several aspects. In a guided inquiry learning model, there are six phases which include the following: focusing the attention of students and explaining the inquiry process, presenting phenomena or problems, formulating hypotheses to explain a problem, collecting data to test hypotheses, formulating explanations and conclusions, and lastly is to reflect on the thought processes used during the investigation [8]. 
The phase of guided inquiry has a relationship with analyzing activities. In the phase of presenting inquiry problems or phenomena, students practice and study the components of elemental analysis by formulating or identifying problems. In the third phase, students are trained about the components of relationship analysis that appear in formulating hypotheses and analyzing component elements in the form of activities to determine experimental variables. In the fourth phase, students are trained about the components of relationship analysis in the form of data analysis and questions exercises. In the fifth phase or stage, students trained on component analysis of organizational principles embodied in activities formulate conclusions as manifestations of the material concepts in learning activities.

As for research related to the application of the guided inquiry learning model, it has been proven that it can be used to train and improve students' analytical abilities/skills. In research, the application of guided inquiry learning models on chemical equilibrium material can train analytical thinking skills as indicated by the percentage of completeness in all aspects of the analysis of $94 \%$ [9]. Other studies have shown that applying the guided inquiry model can improve critical thinking skills in analysis, as evidenced by an increase in the pretest-posttest scores of students in the high criteria of $43 \%$ and the medium criteria by $53 \%$ [10].

Based on this description, the researchers carried out a study entitled "Application of Guided Inquiry Learning Model on the Rate of Reaction Assisted by the Student Worksheet to Improve the Analytical Skills of Class XI Students."

\section{RESEARCH METHODS}

The research type conducted is pre-experimental, which uses only one class without a control class [11]. The subjects ofstudy this were students of class XI IPA 1 SMA Kemala Bhayangkari 1 Surabaya with a total of 32 students. The material used for research is the factors that affect the reaction rate. The design used in this research is One Group Pretest Posttest Design, applied only to one class group without using a control/comparison group [12]. This design compares the results of the pretest and posttest, which are estimated as the results of the treatment, namely the guided inquiry model.

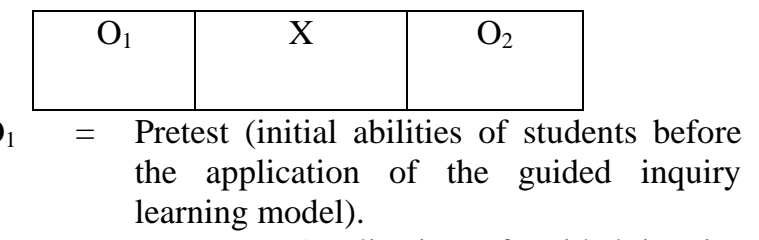

$\mathrm{X}=$ Treatment (application of guided inquiry learning model).

$\mathrm{O}_{2}=$ Posttest (the final ability of students after being treated with a guided inquiry model).

This study uses the syllabus, lesson plans, and worksheet. Research instruments are tools used to collect more complete data and information. The research instrument is used to measure the variable's value under study [13]. The instruments used were the observation sheet on implementing the guided inquiry model, the student activity observation sheet, the analytical ability test sheet, and the response questionnaire sheet. The tools and instruments of this research have passed the stage of review and validation by supervisors and validators. The method of observation is used to observe the implementation of the guided inquiry learning model and the activities of students during the learning process [14]. The test method was used to assess the students' analytical abilities/skills known from the pretest and posttest results and the questionnaire method to obtain response data from students after using the guided inquiry learning model.

The purpose of observing the implementation of the learning model is to obtain teacher quality results in classroom learning. The implementation of the learning model is assessed on a scale of 0-4 at each step [15]. The calculation formula for obtaining the final score is as follows:

$$
\% \text { implementation }=\frac{\text { score earned }}{\text { maximum score }} 100
$$

The scores obtained are adjusted to the criteria presented in table 1 below.

Table 1. Criteria for implementing the learning model

\begin{tabular}{cc}
\hline Score & Criteria \\
\hline $0-25$ & Very less \\
$26-50$ & Enough \\
$51-75$ & Good \\
$76-100$ & Very Good
\end{tabular}

$[16]$

The implementation of learning is said to be carried out if the teacher in managing learning has obtained a score above 50 or is in good and very good criteria.

Observation of student activities aims to see student activities that are relevant or appropriate when learning is carried out with the syntax of the guided inquiry model. Student activities were analyzed using the following equation:

$\%$ students activity $=\frac{\text { frequency of activity that appears }}{\text { frequency of all activity }} \times 100 \%$

The percentage results show that students are active well and can improve their skills if the percentage of student activities related to learning is more than equal to $61 \%$.

The results of the analytical ability test were used to see whether or not there was an improvement before 
and after learning using the guided inquiry model. The improvement of student analytical ability can be known based on the results of pretest and posttests on the material factors that affect the rate of reaction. The following formula calculates the value:

$\%$ value of students' analytical skills $=\frac{\text { score earned }}{\text { maximum score }} \times 100 \%$

The improvement of understudies' analytical abilities can be determined by observing the value of the gain score, utilizing the accompanying formula:

$$
\text { Gain score }=\frac{\text { posttest }- \text { pretest }}{\text { maximum score }- \text { pretest }}
$$

The result of the gain score is deciphered with the suitable classifications in Table 2 beneath:

Table 2. N-Gain Score

\begin{tabular}{cc}
\hline Score & Criteria \\
\hline$\geq 0,7$ & High \\
\hline $0,7><\mathrm{g}>\geq 0,3$ & Medium \\
\hline$<\mathrm{g}><0,3$ & Low \\
\hline
\end{tabular}

It can be analyzed using Paired sample t-test with SPSS to determine the influence of the guided inquiry learning model on the results of student abilities assessed through the pretest and posttest results.

The student response questionnaire sheet serves to obtain the results of student responses to learning that applies the guided inquiry model. The results of the quantitative analysis were measured using the Guttman scale [18].

Table 3. Guttman Scale

\begin{tabular}{ll}
\hline \multicolumn{2}{c}{ Guttman Scale } \\
\hline 1 & Yes \\
0 & No \\
\hline
\end{tabular}

The results of the responses are calculated using the following formula:

$$
\% \text { students responses }=\frac{F}{N} \times 100 \%
$$

If a student's answer arrives at a level of $61 \%$, it is accepted that all understudies concur and have positive reactions to the assertion. This guided inquiry learning is viable for learning and could improve analytical skills.

\section{RESULTS AND DISCUSSION}

\section{Implementation of the learning model}

The application of the guided inquiry learning model in this study was observed by comparing the implementation of the learning steps in the lesson plans and the teacher's practice directly during classroom learning. This analysis aims to determine the quality of teacher teaching practices during classroom learning. The observers who observed the implementation of the guided inquiry learning model were three chemistry education students who were peers; the observations were carried out in two meetings.

The results of the observation of the implementation of the guided inquiry learning model conducted during two meetings are shown in Figure 1 below.

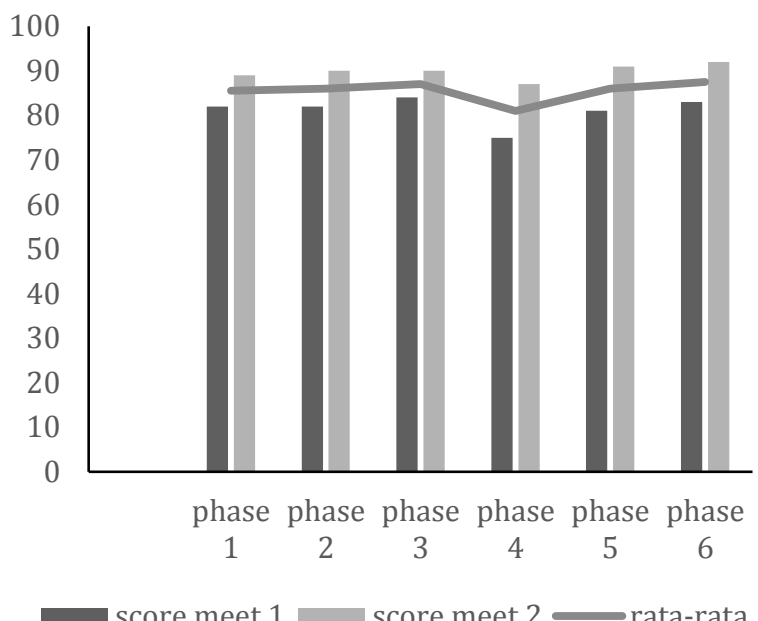

Figure 1. Implementation of the Guided Inquiry Learning Model

In Figure 1, it is shown that the score of the implementation of the guided inquiry learning model from the first phase to the sixth phase at meetings I and II have increased. It indicates if the teacher can implement or carry out the guided inquiry learning model phases with good categories. The results shown in the image above are the scores for each phase from meetings 1 and 2 have good and very good categories. From this category, it can be said that the teacher has the ability in classroom management because, during the lesson, it is good and coherent according to the lesson plan. This learning, it can train and improve students' analytical skills.

Observation of this guided inquiry learning model using the learning implementation are observation sheet instruments. The aim is to determine whether the learning follows the existing syntax. The guided inquiry syntax used in this study has 6 phases, including focusing students' attention and explaining the inquiry process, presenting a phenomenon or problem, formulating a hypothesis to describe an issue, collecting data to test hypotheses, formulating explanations and conclusions. The last one is to reflect on the thought processes used during the investigation.

The researcher acts as a teacher who is a facilitator and mentor for students. The goal is to improve and practice their analytical skills to find concepts related to the sub-material factors that affect the rate of reaction. With this, students can be more active and analytical in learning.

Phase 1 focuses the attention of students and 
explains the inquiry process. The learning exercises include: focusing the attention of understudies, giving apperception, That is, reviewing material related to reaction rates and collision theory to prompt students to recall previously studied material and facilitate further material, then motivating students by providing pictures or examples of related phenomena from everyday life, and finally giving directions. In Figure 1, it can be seen that the implementation score for learning at meeting 1 has a score of 82 , while the score for meeting two has increased to 89 .

In phase 2, the learning steps are forming groups, distributing worksheets, and giving students instructions to read and then understand the phenomenon listed in the worksheet. At the first meeting, learning gets 82 , and at the second meeting, the score is 90 . The learning steps in phase 3 include: identifying problems, formulating problems, formulating hypotheses, and determining experimental variables. The score results for meeting 1 and meeting 2 are 84 and 90, respectively.

Phase 4 encourages students to collect data to test hypotheses by collecting and organizing the data obtained. Meeting 1 scored 75, and at the meeting 2 got a score of 87 . The learning steps in phase 5 include students processing data, analyzing data, discussing, communicating the results obtained, and formulating conclusions. The implementation scores at meetings 1 and 2 were 81 and 91 . The last phase in the guided inquiry learning model was to reflect on problems and thought processes during exploration/investigation, namely by providing reinforcement and giving rewards to groups who were active during learning. Meeting 1 obtained an implementation score of 83 , and the score at meeting 2 was 92 .

Based on the results of data analysis for the implementation of the guided inquiry learning model, it can be concluded that the teacher can apply the steps of learning activities according to the current phases to train and improve participants' analytical skills.

\section{Student Activities}

Students' guided inquiry learning activities are calculated by observing the most prevalent student activities every three minutes. Three observers observed this activity. The purpose of this observation is to assess the seriousness of students when learning in class and efforts to practice analytical skills and determine the percentage of activities that are following the steps of guided inquiry learning.

Activities of students in two sessions using the inquiry learning model show if students practice analysis. It is evident from the percentage of activity time related to analyzing in the first and second meeting is equal to $77.2 \%$ and $81.99 \%$. In addition, the percentage of student activities that are appropriate/relevant to learning activities in meetings 1 and 2 are $94.16 \%$ and $97.11 \%$, respectively.

\section{Students' analytical skills}

An increase in students' analytical ability can be obtained through the results of the pretest was taken before learning using the guided inquiry model, and the score results were posttest taken at the end, after the implementation of the guided inquiry model. The purpose of this data analysis is to compare students' ability in the analysis before and after the implementation of the guided inquiry learning model. The analytical skills trained in this research are analysis of elemental, relationship analysis, and organizational principles. In the analysis of elemental problem indicators or phenomena related to daily life, student's task is to solve the elements contained in the related problem. Relationship analysis contains directions and instructions for students to analyze the relationships that exist in the problems presented by organizing the observational data obtained. At the same time, the analysis of organizational principles is formulating indicators with relevant theoretical concepts.

In presenting inquiry problems or phenomena, students practice elemental analysis whose activity is to formulate a problem. In the third phase, students practice relationship analysis, whose activities are formulating hypotheses, and practice elemental analysis, whose form of activity is to determine the variables of an experiment. In the fourth phase, practice analysis, whose activities are to analyze data and practice questions. In the fifth phase, students practice analyzing organizational principles; the activity is to formulate conclusions. The effect of the treatment during the research, namely the guided inquiry learning model, on enhancing students' analytical skills was determined using the pretest and posttest findings, which were then evaluated using the paired sample t-test. The results obtained are listed in Table 4 below.

Table 4. The results of the Paired sample t-test

\begin{tabular}{lrrrr}
\hline Data & average & $\mathrm{n}$ & $\mathrm{T}$ & $\begin{array}{l}\text { Sig.(2- } \\
\text { tailed) }\end{array}$ \\
\hline Pretest & 21,8 & 30 & & \\
Posttest & 89,1 & 30 & $-33,00$ & 0,00 \\
\hline
\end{tabular}

In table 4 , it can be seen that the tailed sig. 2 obtained is 0.00 ; this indicates that the treatment or guided inquiry learning model applied has a significant and large influence on students' analytical abilities. As for seeing how much the increase is done with the test again. The analysis ability of students calculated as a whole has an average value of 89 with a percentage gain score on the high criteria of $85.81 \%$. The guided inquiry learning model can be proved to be very helpful in improving students' analytical skills based on these data. The results of the gain score for the components of students' analytical abilities are shown in Figure 2 below. 


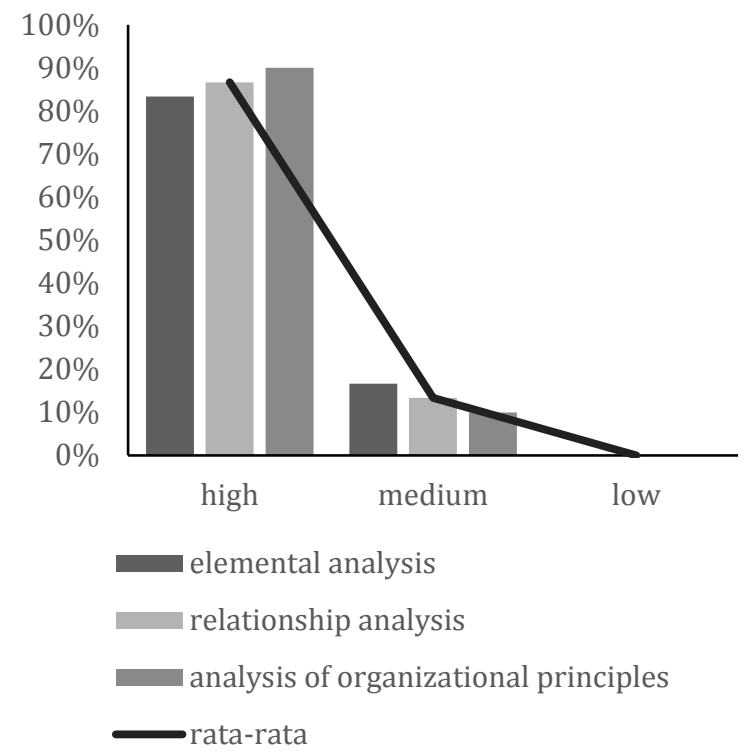

Figure 2. Students' Analytical Ability

Based on Figure 2 above, in the elemental analysis component, the percentage gain score obtained on the high to low criteria is $83.33 \%, 16.67 \%$, and $0 \%$, respectively. In the relationship analysis component, the percentage gain scores obtained on the high to low criteria are $86.67 \%, 13.33 \%$, and $0 \%$, respectively. In the organizational principles analysis component, the percentage gain score is $90 \%$ on high criteria and $10 \%$ on medium criteria.

The guided inquiry learning model can be used to train and improve students' analytical skills based on the result of these data. This outcome is also supported by theory; one of the purposes of guided inquiry learning is to build and strengthen students' logical, analytical, and critical thinking skills [19].

\section{Student Responses}

Responses of students can be known by using a questionnaire, which is used to record student responses to learning that uses the guided inquiry learning methodology to help students improve their analytical abilities on the material rate of reaction. The results of the answers were analyzed using the Guttman rating scale. If students answer "yes," then the score is 1 . but if students answer "no," then the score is 0 [18]. The respondents were 30 students. The results of student responses are shown in Figure 3 below.

According to figure 3,87 percent of students (or 26 students out of a total of 30 students) state that learning utilizing guided inquiry learning can help them develop and strengthen their analytical skills, especially in the sub-material factors that affect reaction rates. In comparison, $13 \%$ or four students answered no. Because the percentage is above $61 \%$, it is assumed that all students agree and have a positive response to the statement and this guided inquiry model is effective for use in the student learning process [20].

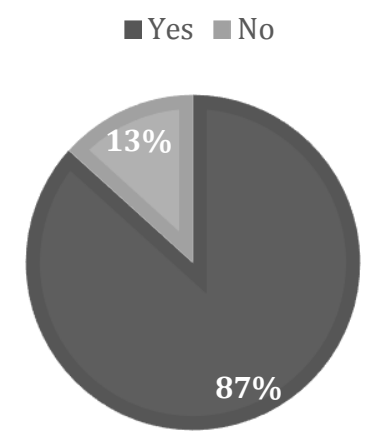

Figure 3. Student Responses

\section{CONCLUSION}

The subjects of study were students of class XI IPA 1 SMA Kemala Bhayangkari 1 Surabaya with 32 students. The material used for research is the factors that affect the reaction rate. The results of the analysis ability of students as a whole have an average value of 89 with a percentage gain score on the high criteria of $85.81 \%$. These results indicate that the guided inquiry learning model assisted by student worksheets effectively improves students' analytical skills in the rate of reaction topic.

\section{REFERENCES}

[1] Made, Wena. (2011). Strategi Pembelajaran Inovatif Kontemporer: Suatu Tinjauan. Konseptual Operasional. Jakarta: PT. Bumi Aksara.

[2] Achmad, Hiskia dan Bardja, Lubna. (2012). Demonstrasi Sains Kimia: Kimia Deskriptif Melalui Demo Kimia. Bandung: Nuansa.

[3] Khasanah, Nikmatul dan Azizah, Utiya. (2018). Melatihkan Keterampilan Berpikir Kritis Siswa Melalui Penerapan Model Kooperatif Tipe Group Investigation (GI) pada MateriLaju Reaksi di SMA Negeri 1 Manyar. UNESA Journal of Chemical Education. Vol. 7 (1): hal. 81-86.

[4] Suherman, E. dan Sukjaya, Y. (1990). Petunjuk Praktis untuk Melaksanakan Evaluasi Pendidikan Matematika. Bandung:Wijayakusumah.

[5] Arantika, J., Saputro, S., \& Mulyani, S. (2019). Effectiveness of guided inquiry-based module to improve science process skills. In Journal of physics: conference series (Vol. 1157, No. 4, p. 042019). IOP Publishing.

[6] Bloom, B.S. (1956). Taxonomy of Educational Objectives: Handbook 1, Cognitive Domain. New York: David McKay.

[7] Trianto. (2011). Model Pembelajaran Terpadu Konsep Strategi Dan Implementasinya Dalam Kurikulum Tingkat Satuan Pendidikan. Jakarta : Bumi Aksara.

[8] Hidayah, R., \& Anggraeni, L. (2018). The Effectiveness of Guided Inquiry-Based Students Practicum Worksheet to Promote Science Process Skills In Reaction Rate. Proceedings of ICST 2018, 1, 11-13. 
[9] Novitasari, Putri dan Muchlis. (2020). Penerapan Model Pembelajaran Inkuiri Terbimbing Untuk Meningkatkan Keterampilan Berpikir Analisis Siswa Pada Materi Kesetimbangan Kimia Kelas XI SMA Negeri 4 Sidoarjo. UNESA Journal of Chemical Education. Vol. 9 (1): hal. 16-20.

[10] Herjinda, Winda dan Muchlis. (2015). Penerapan Model Pembelajaran Inkuiri Terbimbing untuk Melatihkan Keterampilan Berpikir Kritis pada Materi Pokok Asam Basa Kelas XI SMAN 2 Magetan. UNESA Journal of Chemical Education. Vol. 4 (2): hal. 325-332.

[11] Sugiyono. (2015). Metode Penelitian Pendidikan. Bandung: Alfabeta.

[12] Mahyuna, M., Adlim, M., \& Saminan, I. (2018). Developing guided-inquiry-student worksheets to improve the science process skills of high school students on the heat concept. In Journal of Physics: Conference Series (Vol. 1088, No. 1, p. 012114). IOP Publishing.

[13] Sugiyono. (2016). Quantitative, Qualitative and $R \& D$ Research Methods. Bandung : PT Alphabet.

[14] Devi Wahyuningtyas, Utiya Azizah . (2013) . Implementation Of Inquiry Learning Model To Train Process Skill In Acid Base Matter For Grade XI Student Of Sma Negeri 15 Surabaya. UNESA Journal of Chemical Education, Vol. 2, No. 2, pp. 101-107.

[15] Munfaricha, F., \& Ismono. (2018). Penerapan Lembar Kerja Siswa (LKS) Berbasis Inkuiri Terbimbing dalam Meningkatkan Keterampilan Berpikir Kritis Siswa pada Sub Materi FaktorFaktor yang Mempengaruhi Laju Reaksi. Unesa Journal of Chemical Education.

[16] Sudjana. 2006. Metode Statistik. Jakarta: Rineka Cipta

[17] Hake, Richard. R. (1999). Analyzing Chane/Gain Score. AREA-D American Education Research Association's Division Measurement and Research Methodology.

[18] Aprillia, R. D. (2016). Implementation Of Semi Guided Inquiry Learning Model To Practice Students'Critical Thinking Skill At Polar And Non Polar Covalent Bonding Topic. UNESA Journal of Chemical Education, 5(1).

[19] Sanjaya, Wina. (2008). Strategi Pembelajaran Berorientasi Standar Proses Pendidikan. Jakarta: Prenada Media Goup.

[20] Wulansari, N. E. (2020). Implementation of Guided Inquiry Learning Models Train Critical Thinking Skills In Reaction Rate Materials For Eleven Class SMAN 3 Lamongan. UNESA Journal of Chemical Education, 9(1).

[21] Sudarsana, I M. 2010. Pembuatan Program Pembelajaran Interaktif Laju Reaksi Berbantuan Komputer untuk Pembelajaran Kimia SMA. Skripsi tidak dipublikasikan. Singaraja: Universitas Pendidikan Ganesha.
[22]Fauziah, N., Hakim, A., \& Andayani, Y. (2019). Meningkatkan literasi sains peserta didik melalui pembelajaran berbasis masalah berorientasi green chemistry pada materi laju reaksi. Jurnal Pijar MIPA, 14(2), 31-35. 